\title{
PROMOSI KESEHATAN TENTANG PENGGUNAAN ALAT PELINDUNG DIRI (APD) PADA PEKERJA PEMBUAT BATU BATA
}

\author{
Rosita Ginting $^{1 *}$, Irmayani ${ }^{2}$, Anggi Isnani Parinduri², Ismail Sirait ${ }^{2}$ \\ ${ }^{1}$ Program Studi Keperawatan, Institut Kesehatan Medistra Lubuk Pakam \\ ${ }^{2}$ Program Studi Kesehatan Masyarakat, Institut Kesehatan Medistra Lubuk Pakam \\ JIn. Sudirman No.38 Lubuk Pakam, Kabupaten Deli Serdang, \\ Sumatera Utara - Indonesia \\ *email korespondensi author: rositaginting25@gmail.com
}

DOI $10.35451 /$ jpk.v1i1.768

\begin{abstract}
Abstrak
Angka kecelakaan kerja pada pekerja terus meningkat dari tahun ke tahun. Salah satu penyebab terjadinya kecelakaan kerja yaitu masih kurangnya kepedulian pekerja untuk menggunakan APD pada saat bekerja. Setiap kecelakaan mempunyai penyebab yang berbeda-beda yang disebabkan oleh faktor penyebab kecelakaan baik secara langsung maupun tidak langsung.Tulisan ini bertujuan untuk memberikan promosi kesehatan kepada pekerja pembuat batu bata tentang pentingnya penggunaan APD saat bekerja. Kegiatan ini dilakukan dengan metode observasi dan pemberian penyuluhan serta pemberian leaflet. Kegiatan ini dilakukan di Desa Sidodadi Kecamatan Beringin Kabupaten Deli Serdang pada tanggal 22 April 2021 dengan sasaran pekerja pembuat batu bata. Diawali dengan melakukan studi pendahuluan untuk mengetahui permasalahan yang ada di wilayah pelaksanaan pengabdian masyarakat. Setelah dilakukan observasi kemudian pada saat kegiatan pengabdian sebelum penyuluhan dilakukan pre test untuk mengetahui tingkat pengetahuan sasaran tentang pentingnya penggunaan APD kemudian dilakukan penyuluhan dan setelah penyuluhan, dilakukan post test untuk mengetahui gambaran pengetahuan tentang penggunaan APD setelah dilakukannya penyuluhan. Dari hasil kegiatan yang dilakukan pekerja antusias menyambut kegiatan ini. Mayoritas tingkat pengetahuan pekerja pembuat batu bata berada pada kategori kurang baik sebanyak 30 orang $(71,43 \%)$ sebelum dilakukan penyuluhan dan setelah dilakukan penyuluhan mayoritas pengetahuan pekerja pembuat batu bata memiliki pengetahuan yang baik sebanyak 33 orang (78,57\%). Terjadi peningkatan pengetahuan baik sebesar $50 \%$ pada kategori pengetahuan baik setelah penyuluhan. Harapannya dengan adanya kegiatan ini terjadi peningkatan kepatuhan pekerja pembuat batu bata dalam menggukan APD pada saat bekerja.
\end{abstract}

Kata kunci: Promosi Kesehatan, Edukasi Kesehatan, Alat Pelindung Diri

\begin{abstract}
The number of work accidents in workers continues to increase from year to year. One of the causes of work accidents is the lack of awareness of workers to use PPE at work. Each accident has different causes which are caused by factors that cause accidents either directly or indirectly. This paper aims to provide health promotion to brick-making workers about the importance of using PPE when working. This activity was carried out using the method of observation and providing counseling as well as giving leaflets. This activity was carried out in Sidodadi Village, Beringin District, Deli Serdang Regency on April 22, 2021 with the target of brick-making workers. It begins with conducting a preliminary study to find out the problems that exist in the area of community service implementation. After observation, then during service activities before counseling, a pre test was carried out to determine the target's level of
\end{abstract}


Received: 20 June 2021 :: Accepted: 23 June 2021 :: Published: 30 June 2021

knowledge about the importance of using PPE then counseling was carried out and after counseling, a post test was carried out to determine the description of knowledge about the use of PPE after counseling From the results of the activities carried out, the workers enthusiastically welcomed this activity. The majority of the knowledge level of brick-making workers was in the poor category as many as 30 people (71.43\%) before counseling and after counseling the majority of knowledge brick-making workers had good knowledge as many as 33 people (78.57\%). There was an increase in good knowledge by $50 \%$ in the good knowledge category after counseling. It is hoped that with this activity there will be an increase in the compliance of brick-making workers in using PPE at work.

Keywords: Health promotion, Health education, Personal Protective Equipment

\section{Pendahuluan}

Data BPJS Ketenagakerjaan menunjukkan bahwa pada tahun 20172018 menunjukkan bahwa Indonesia memiliki angka kecelakaan yang cukup tinggi. Tahun 2017 mencapai 105.383 kasus dengan cacat fungsi sebanyak 3.618 kasus, cacat sebagian sebanyak 2.616 kasus, cacat total sebanyak 43 kasus, dan meninggal sebanyak 2.375 kasus. Angka kecelakaan kerja tahun 2018 mencapai 105.182 kasus dengan korban meninggal dunia sebanyak 2.375 orang (Badan Penyelenggara Jaminan Sosial Ketenagakerjaan, 2018). Setiap kecelakaan mempunyai penyebab yang berbeda-beda yang disebabkan oleh faktor penyebab kecelakaan yang langsung maupun tidak langsung berkaitan. Kegiatan proses pekerjaan dengan tidak memakai APD merupakan salah satu perilaku tidak aman yang bisa menimbulkan risiko keparahan akibat kecelakaan kerja serta penyakit akibat kerja sehingga dapat menyebabkan kerugian baik dirasakan oleh tenaga kerja itu sendiri maupun dari pihak perusahaan.

Perasaan kurang nyaman merupakan salah satu alasan kebanyakan pekerja tidak menggunakan APD saat bekerja. Kesadaran akan manfaat penggunaan APD perlu ditanamkan pada setiap pekerja. Pembinaan secara kontinu dapat meningkatkan kesadaran dan wawasan mereka. Cara yang efektif untuk meningkatkan kesadaran pekerja untuk menggunakan APD dengan melaksanakan pelatihan. Peningkatan wawasan dan pengetahuan dapat membuat pekerja sadar tentang pentingnya penggunaan APD, sehingga efektif dan benar dalam penggunaannya (Budiono, 2017 : 335).

Salah satu promosi yang aman yaitu dengan melakukan komunikasi K3. PP 50 tahun 2012, menyebutkan bahwa komunikasi K3 merupakan bagian dari kegiatan pendukung untuk pencegahan kecelakaan kerja. Berbagai contoh upaya safety promotion adalah safety sign, safety induction, dan safety talk (Primadana, 2016).

Kecamatan Beringin adalah tempat terbanyak pembuatan batu bata tepatnya di Desa Sidourip. Batu bata di buat melalui proses pencampuran tanah, pencetakan batu bata, penjemuran, pemasukan/penyusunan batu bata ke pembakaran, pembakaran batu bata dan pendindingan kembali batu bata. Berdasarkan hasil survey awal, diketahui bahwa sebagian bsesar pekerja tidak menggunakan APD pada saat melakukan pekerjaan mereka. Berdasarkan data juga, pada tahun 2019 ditemukan ada pekerja yang mengalami kecelakaan dan kehilangan salah satu anggota tubuhnya seperti kaki dikarenakan pada saat melaksanakan pekerjaannya, pekerja tidak menggunakan APD dan juga pekerja pernah terjatuh pada saat bekerja dikarenakan kondisi lingkungan yang tidak aman.

\section{Metode}

Metode yang diterapkan pada kegiatan Pengabdian Kepada 
Received: 20 June 2021 :: Accepted: 23 June 2021 :: Published: 30 June 2021

Masyarakat (PKM) ini berupa observasi dan pemberian promosi kesehatan. Kegiatan observasi dilakukan untuk mengetahui permasalahan pada tempat dilakukannya kegiatan pengabdian kepada masyarakat. Kegiatan promosi kesehatan melalui penyuluhan. Sebelum kegiatan penyuluhan, dilakukan pengukuran tingkat pengetahuan pekerja tentang APD kemudian dilakukan penyuluhan dan setelah itu dilakukan pengukuran kembali tingkat pengetahuan pekerja tentang APD. Media yang digunakan pada saat penyuluhan yaitu proyektor dan LCD untuk pemaparan materi beserta leaflet. Sasaran pada kegiatan ini yaitu pekerja pembuat batu bata. PKM dilakukan di Desa Sidodadi Kecamatan Beringin pada bulan April 2021.

\section{Hasil dan Pembahasan}

Kegiatan PKM dilakukan di Desa Sidodadi Kecamatan Beringin Kabupaten Deli Serdang pada tanggal 22 April 2021. Peserta pada kegiatan ini sebanyak 42 orang. Pelaksanaan kegiatan PKM ini diawali dangan memberikan kuesioner yang berisi pertanyaan tentang APD untuk mengetahui sejauh mana pengetahuan peserta tentang pentingnya penggunaan APD pada saat bekerja. Setelah kuesioner selesai diisi, kemudian dikumpulkan kepada tim. Selanjutnya dilakukan penyuluhan kesehatan secara tatap muka kepada peserta. Pada kesempatan yang sama, tim PKM juga membagikan leaflet yang berisi informasi tentang pentingnya penggunaan APD. Setelah pemaparan materi, peserta diberi kesempatan untuk menanyakan hal yang masih kurang di pahami. Peserta sangat antusias mengikuti kegiatan ini. Hal ini ditunjukkan dengan pertanyaanpertanyaan yang disampaikan oleh peserta setelah paparan materi. Setelah kegiatan penyuluhan, tim PKM memberikan kuesioner keembali kepada peserta sebgai evaluasi dari materi yang sudah disampaikan. Hasil olahan data terkait gambaran pengetahuan peserta sebelum dan seudah kegiatan penyuluhan disajikan pada tabel berikut:
Tabel 1. Distribusi Pengetahuan Pekerja Pembuat Batu Bata Sebelum Penyuluhan APD

\begin{tabular}{lrr}
\hline Pengetahuan & N & \multicolumn{1}{c}{$\%$} \\
\hline Baik & 12 & 28,57 \\
Kurang baik & 30 & 71,43 \\
\hline Total & 42 & 100,00 \\
\hline
\end{tabular}

Tabel 1 menunjukkan bahwa sebelum dilakukan penyuluhan tentang APD, mayoritas tingkat pengetahuan pekerja pembuat batu bata berada pada kategori kurang baik sebanyak 30 orang $(71,43 \%)$

Tabel 2. Distribusi Pengetahuan Pekerja Pembuat Batu Bata Setelah Penyuluhan APD

\begin{tabular}{lrr}
\hline \multicolumn{1}{c}{ Pengetahuan } & N & \multicolumn{1}{c}{$\%$} \\
\hline Baik & 33 & 78,57 \\
Kurang baik & 9 & 21,43 \\
\hline \multicolumn{1}{c}{ Total } & 42 & 100,00 \\
\hline
\end{tabular}

Tabel 2 menunjukkan bahwa setelah dilakukan penyuluhan tentang $A P D$, pengetahuan pekerja pembuat batu bata memiliki pengetahuan yang baik sebanyak 33 orang (78,57\%). Berdasarkan data yang didapatkan ternyata terjadi peningkatan pengetahuan yang signifikan pada pekerja pembuat batu terkait pentingnya penggunaan APD. Jika dilihat dari data, setelah dilakukan penyuluhan terjadi peningkatan sebesar $50 \%$ pada kategori pengetahuan baik. Dari data ini, dapat diketahui bahwa pnyuluhan efektif untuk merubah pengetahuan, dari pengetahuan kurang baik menjadi pengetahuan baik. Berdasarkan hasil ini, dengan meningkatnya pengetahuan pekerja tentang pentingnya menggunakan APD saat bekerja, harapannya akan selaras dengan tindakan untuk menggunakan APD pada saat bekerja sehingga tingkat kecelakaan saat bekerja dapat diminimalisir.

Pengetahuan pekerja tentang alat pelindung diri akan berpengaruh terhadap perilaku dalam menggunakan APD secara lengkap pada saat bekerja. Menurut hasil penelitian yang dilakukan Joyo (2017) pekerja yang patuh memiliki pengetahuan dan kesadaran untuk melindungi dirinya terhadap bahaya keselamatan kerja dan akan berperilaku aman dalam melaksanakan 
pekerjaannya, sebaliknya pekerja yang tidak patuh akan cenderung melakukan kesalahan dalam setiap proses kerja karena tidak mematuhi standar dan peraturan yang ada. Hal inilah yang dapat meningkatkan peluang terjadinya kecelakaan kerja ringan bahkan kecelakaan kerja yang lebih berat.

\section{Kesimpulan}

Kecelakaan kerja yang dialami oleh pekerja pada saat bekerja akan berdampak pada pekerja dan perusahaan. Kepatuhan penggunaan APD pada saat bekerja akan meminimalisir kejadian kecelakaan. Edukasi terkait penggunaan APD terus dilakukan untuk menumbuhkan kesadaran pekerja dalam menggunakan APD.

\section{Ucapan Terima Kasih}

Ucapan terima kasih disampaikan kepada Institut Kesehatan Medistra Lubuk Pakam, Lembaga Penelitian dan Pengabdian kepada Masyarakat, Kepala Desa Sidourip Kecamatan Beringin Kabupaten Deli Serdang dan semua pihak yang telah mendukung kegiatan PKM ini yang tidak dapat disebutkan.

\section{Daftar Pustaka}

Badan Penyelenggara Jaminan Sosial Ketenagakerjaan. (2018). Angka Kecelakaan Kerja Karyawan di Indonesia Tahun 2016 - 2018. Jakarta.

Budiono, (2017). Hiperkes dan Kesehatan Kerja, Semarang : Badan Penerbit Universitas Diponegoro.

Joyo, T. (2017). Pengaruh Pemberian Penyuluhan K3 Terhadap Tingkat Kedisiplinan Pekerja Dalam Pemakaian Alat Perlindungan Diri (APD) Di PT. Djitoe Indonesia Tobacco. Skripsi. Surakarta: FKM Universitas Muhammadiyah Surakarta.

PP 50 tahun (2012). upaya Safety Promotion dalam bentuk komunikasi $\mathrm{K} 3$.

Primadana, Try Sadewo. (2016). Analisis Efek tifitas Implementasi Safety Promotion pada Pekerja di PT Lautan Otsuka Chemical Tahun
2012. Jakarta : Universitas Indonesia. 